AJHSE Vol: 1 (2): 24-36, 2020

Article Ref. No.: AJHSE010204

Accepted Date: October 01, 2020

(C) 2020. CC License 4.0

www.ajhse.org

\title{
EXPOSURE OF COWPEA (vigna unguiculata (l) walp) TO SPENT ENGINE OIL CONTAMINATED SOIL AND ITS IMPLICATIONS ON CONSUMER'S HEALTH
}

\author{
${ }^{* 1}$ Bello T. B., ${ }^{2}$ Bolaji O. M. and ${ }^{3}$ Fakunle A. G.
}

\author{
${ }^{*}$ Department of Community Medicine, Osun State University \\ 2Institute for Medical Research and Training, University of Ibadan, Ibadan, Nigeria \\ 3Department of Occupational and Environmental Health, University of KwaZulu-Natal, Durban, South Africa \\ *Corresponding Author Email: temilade.bello@uniosun.edu.ng Phone: +2348060726515
}

\begin{abstract}

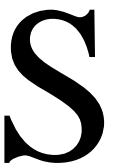

pent Engine oil (SEO) is a common environmental pollutant generated after engine services. Disposing SEO is a serious environmental issue in Nigeria as generators end up disposing it in water drain systems, rivers, open vacant plots and agricultural lands. Thus, the need to assess the impact of such disposal on environmental components becomes imperative. Using a completely randomized design, a control and seven treatments of SEO (T0: $0 \mathrm{ml}, \mathrm{T} 1: 5 \mathrm{ml}, \mathrm{T} 2: 10 \mathrm{ml}, \mathrm{T} 3: 15 \mathrm{ml}$, T4: $20 \mathrm{ml}, \mathrm{T} 5: 25 \mathrm{ml}$, T6: $50 \mathrm{ml}$, T7: $75 \mathrm{ml}$ ) were applied to potted soil for cowpea planting. Plant height, leave number, yield, heavy metal load and hazard quotient were assessed. Baseline heavy metal analysis showed the SEO contained lead and cadmium at $0.003 \mathrm{mg} / \mathrm{kg}$ and 0.462 $\mathrm{mg} / \mathrm{kg}$ respectively. There was significant reduction in plant height $(\mathrm{T} 0: 50.72 \mathrm{~cm}, \mathrm{~T} 3: 37.36 \mathrm{~cm}, \mathrm{~T} 7: 24.33 \mathrm{~cm}$ ), number of leaves (T0: 25.91, T3: 21.57, T7: 17.67), seed weight (T0: $24.40 \mathrm{~g}$, T3: $16.38 \mathrm{~g}$, T7: $5.03 \mathrm{~g}$ ) and plant weight (T0: $171.60 \mathrm{~g}$, T3: $136.60 \mathrm{~g}, \mathrm{T7}: 54.70 \mathrm{~g})$ in contaminated soil with increasing SEO concentration $(\mathrm{P}<0.05)$. Cowpea grown on contaminated soil accumulated cadmium in seeds (T0: $0.000 \mathrm{mg} / \mathrm{kg}, \mathrm{T} 3: 0.057 \mathrm{mg} / \mathrm{kg}, \mathrm{T} 70.119$ $\mathrm{mg} / \mathrm{kg}$ ) and in roots (T0: $0.000 \mathrm{mg} / \mathrm{kg}, \mathrm{T} 3: 0.079 \mathrm{mg} / \mathrm{kg}, \mathrm{T} 7: 0.263 \mathrm{mg} / \mathrm{kg}$ ) with hazard quotient ranging from 0.084 to 0.216 . This study revealed that increasing environmental pollution through indiscriminate SEO increases the possibility of health risk by elevating hazard quotient and this should therefore be discouraged.
\end{abstract}

Keywords: environmental pollution, heavy metals, hazard quotient, SEO

LICENSE: This article by African Journal of Health, Safety and Environment (AJHSE)is licensed and published under the Creative Commons Attribution License 4.0 International License, which permits unrestricted use, distribution, and reproduction in any medium, provided this article is duly cited.

COPYRIGHT: The Author(s) completely retain the copyright of this published article.

OPEN ACCESS: The Author(s) approves that this article remains permanently online in the open access (OA) mode. 


\section{INTRODUCTION}

Adverse impact of spent engine oil (SEO) according to studies has been observed on plants cultivated on SEO polluted soils leading to reduced germination of seeds, yield and increased uptake of toxic components (Akinola et al., 2004). According to Adedokun and Ataga (2007), SEO poses danger to the environment due to its high content in various pollutants both organic and inorganic. The impact of heavy metal contamination on the biological lives has been widely reported especially cadmium and lead which have been found in most crude oil (Raskin and Ensley, 2000; Meagher, 2000). Pollution from SEO has been said to pose environmental problems in Nigeria and such pollution problem has been noted to be more widely spread than crude oil pollution (Odjegba and Sadiq, 2002). Due to the presence of large quantities of hydrocarbons, toxic polycyclic aromatic hydrocarbons and heavy metals, studies have shown that indiscriminate disposal of SEO may adversely affect plants, microbes and aquatic lives (Wang et al., 2000).

Cowpea is a leguminous crop rich in protein, minerals and vitamins (Tharanathan and Mahadevamma, 2003). According to Food and Agriculture Organization (FAO) (2017), the production of cowpea by West Africa sub-region stands at about 81\% (4,525,891 metric tonnes) of the global production of cowpea (5,589,216 metric tonnes) in 2014. Globally, Nigeria has been rated as the largest consumer of cowpea (Langyintuo et al, 2003) and this may be connected with its relative affordability and high nutritional value. Due to high quality of protein in cowpea, companies are harnessing its nutritional benefits in industrial food formulation (Hamid et al, 2016). Clinical studies have also documented the relevance of cowpea and other legumes in the reduction of cholesterol and the risks associated with coronary heart diseases (Anderson and Major, 2002; Bouchenak and Lamri-Senhadji, 2013).

The aim of this study was to assess the toxic effects imposed on cowpea grown on SEO contaminated soil and its implication on consumer's health while the specific objectives were to determine the:

- impact of SEO on growth parameters of cowpea

- heavy metal load in cowpea seed and root grown on SEO contaminated soil.

- health risk associated with ingestion of cowpea planted on SEO polluted soil.

The study justification is that in Nigeria, disposing SEO is a serious environmental issue due to inadequacy of waste disposal and recycling facilities. Most generators end up disposing it in water drain systems, rivers, open vacant plots and agricultural lands thus, rendering such lands unsuitable for agricultural practices (Anoliefo and Vwioko, 2001). In cases where such polluted lands are not remediated and farmers plant crops on them, consumers of such crops may stand the risk of ingesting pollutants released into the soil via translocation (Baker et al., 2000). It is against these backdrops that this study is targeted at establishing the dangers associated with consumption of crops grown on such contaminated soils.

We hypothesize that:

(1) SEO contaminated soil has no significant toxic effect on cowpea planted on it and

(2) Consumption of cowpea grown on spent engine oil contaminated soil has no significant implication on health.

\section{MATERIALS AND METHODS}

Top soil obtained from agricultural research farm of University of Ibadan was sieved using 2 by $2 \mathrm{~mm}$ sieve. SEO from Maintenance Department, University of Ibadan were pooled in a container and thoroughly mixed to give a homogeneous sample. The soil and SEO were assessed for baseline heavy metals. The artificially contaminated soil 
was put to a weight of $350 \mathrm{~g}$ in planting pots for 7 treatments and a control. Each group (treatment and control) was made in 5 replications making a total of 40 pots. Each treatment group was mixed with varying amount of SEO in the order: $0 \mathrm{ml}$ (T0), $5 \mathrm{ml}$ (T1), 10ml (T2), 15ml (T3), 20ml (T4), 25ml (T5), 50ml (T6) and 75ml (T7) respectively after which soil $\mathrm{pH}$ was measured using $\mathrm{pH}$ meter.

With the experiment being maintained in a screen house, three cowpea seeds were planted in each pot. Growth parameters such as plant height measured with a meter rule and number of leaves counted visually were monitored weekly for ten weeks. At the end of $10^{\text {th }}$ week, the experiment was terminated and each plant was carefully removed from the pot, gently washed under running tap and separated into roots, stem and seed respectively. Harvested samples were immediately oven dried, and milled into powdery form in preparation for digestion and heavy metal analysis. Both root and seed samples for each group were digested separately after which the digested samples were determined for $\mathrm{Pb}, \mathrm{Cd}$ and $\mathrm{Ni}$ on Atomic Absorption Spectrophotometer (AAS). Associated health risk was assessed using hazard quotient (US Environmental Protection Agency (US EPA) 1989). Data generated were analyzed using Statistical Package for Social Sciences (SPSS) version 22.0. Hazard quotient was calculated using the formula:

$$
\mathrm{HQ}=\frac{(\mathrm{D}) \times\left(\mathrm{C}_{\text {metal }}\right)}{\operatorname{Rf} \mathrm{D} \times \mathrm{BO}}
$$

Where

$\mathrm{D}=$ daily intake of food (Cowpea) $(\mathrm{kg} /$ day) taken as $0.1 \mathrm{~kg} /$ day (Marinangeli et al, 2017)

Cmetal $=$ concentration of metal $(\mathrm{mg} / \mathrm{kg})$

Rf $\mathrm{D}=$ reference oral dose of metal (Cadmium) (mg/kg of body weight/day), taken as 0.001 (US EPA, 2000)

$\mathrm{BO}=$ Average body weight $(\mathrm{kg})$ taken as $55 \mathrm{~kg}(\mathrm{ICMR}, 2010)$

An index value $<1$ is assumed to be safe while above 1 is assumed to be unsafe.

\section{RESULTS}

\section{BASELINE HEAVY METAL LOAD IN SOIL AND OIL}

Table 1 presents the baseline heavy metal content of soil and SEO respectively. Both SEO and soil were analysed for $\mathrm{Pb}, \mathrm{Cd}$ and $\mathrm{Ni}$ and it was observed that lead and cadmium were present only in the oil at $0.003 \mathrm{ppm}$ and $0.462 \mathrm{ppm}$ respectively while $\mathrm{Ni}$ was absent in both soil and SEO.

Table 1: Baseline heavy metal load in soil and SEO

\begin{tabular}{cccc}
\hline Samples & Pb & Ni & Cd \\
\hline Soil & $0.000 \pm 0.000 \mathrm{mg} / \mathrm{kg}$ & $0.000 \pm 0.000 \mathrm{mg} / \mathrm{kg}$ & $0.000 \pm 0.000 \mathrm{mg} / \mathrm{kg}$ \\
SEO & $0.003 \pm 0.0001 \mathrm{mg} / \mathrm{L}$ & $0.000 \pm 0.000 \mathrm{mg} / \mathrm{L}$ & $0.462 \pm 0.0001 \mathrm{mg} / \mathrm{L}$ \\
\hline
\end{tabular}

Values are means of 3 replicates

\section{SOIL pH}

The results of soil $\mathrm{pH}$ after application of SEO is presented in Table 2 below. The results reveal that SEO contaminated soil samples across all treatments had $\mathrm{pH}$ ranging between 4.7 and 5.0 
Table 2: Average $\mathrm{pH}$ values of SEO contaminated soil samples before planting

\begin{tabular}{ll}
\hline Treatments & Mean $\mathrm{pH} \pm \mathrm{SD}$ \\
\hline T0 & $4.73 \pm 0.12$ \\
$\mathrm{~T} 1$ & $4.70 \pm 0.10$ \\
$\mathrm{~T} 2$ & $4.97 \pm 0.21$ \\
$\mathrm{~T} 3$ & $4.70 \pm 0.10$ \\
$\mathrm{~T} 4$ & $4.77 \pm 0.15$ \\
$\mathrm{~T} 5$ & $5.00 \pm 0.10$ \\
$\mathrm{~T} 6$ & $4.80 \pm 0.17$ \\
T7 & $4.70 \pm 0.00$ \\
\hline
\end{tabular}

Values are means of 3 replicates.

\section{PLANT GROWTH PARAMETERS}

Figures 1 and 2 show the growth pattern of cowpea on SEO contaminated soil during the period of ten weeks. There was a decreasing growth in plant height and number of leaves from T0 to T7 from 1st week to 10th week. For instance, at the $3 \mathrm{rd}$ week, average height of T0 (control) was $24.2 \mathrm{~cm} \pm 2.21$, T6 $(50 \mathrm{ml}$ ) was $16.6 \mathrm{~cm} \pm 1.39$ while T7 (75ml) attained $14.75 \mathrm{~cm} \pm 2.18$. At $10^{\text {th }}$ week, T0 reached $97.06 \mathrm{~cm} \pm 5.78$; $\mathrm{T} 6$ reached $45.2 \mathrm{~cm} \pm 2.28$ while $\mathrm{T} 7$ reached 39.75 $\mathrm{cm} \pm 2.57$. Similarly, at 3rd and 10th week, average number of leaves on T0 was $13.06 \pm 1.34$ and $46.96 \pm 6.73$; $\mathrm{T} 6$ was $9.2 \pm 1.64$ and $31.3 \pm 2.64$ while $\mathrm{T} 7$ was $8 \pm 0.87$ and $32.75 \pm 1.89$ respectively.

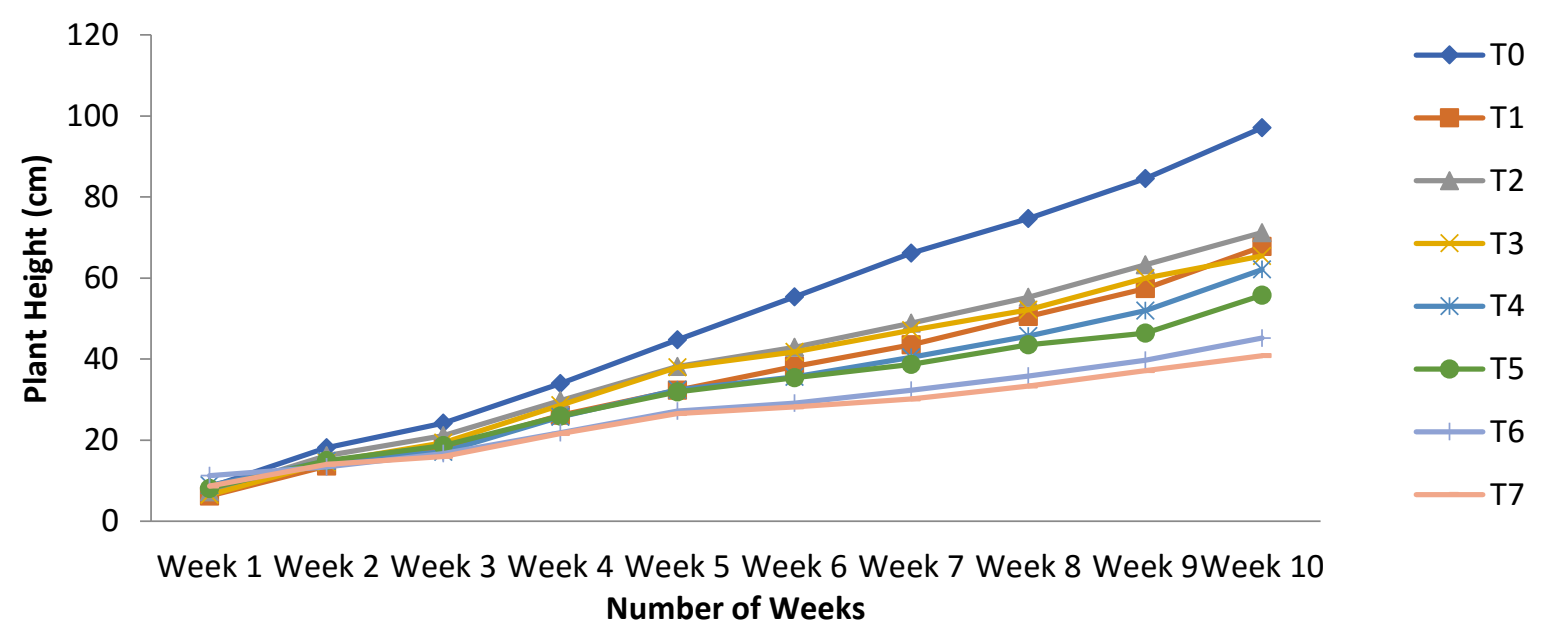

Figure 1: Plant height against number of weeks 


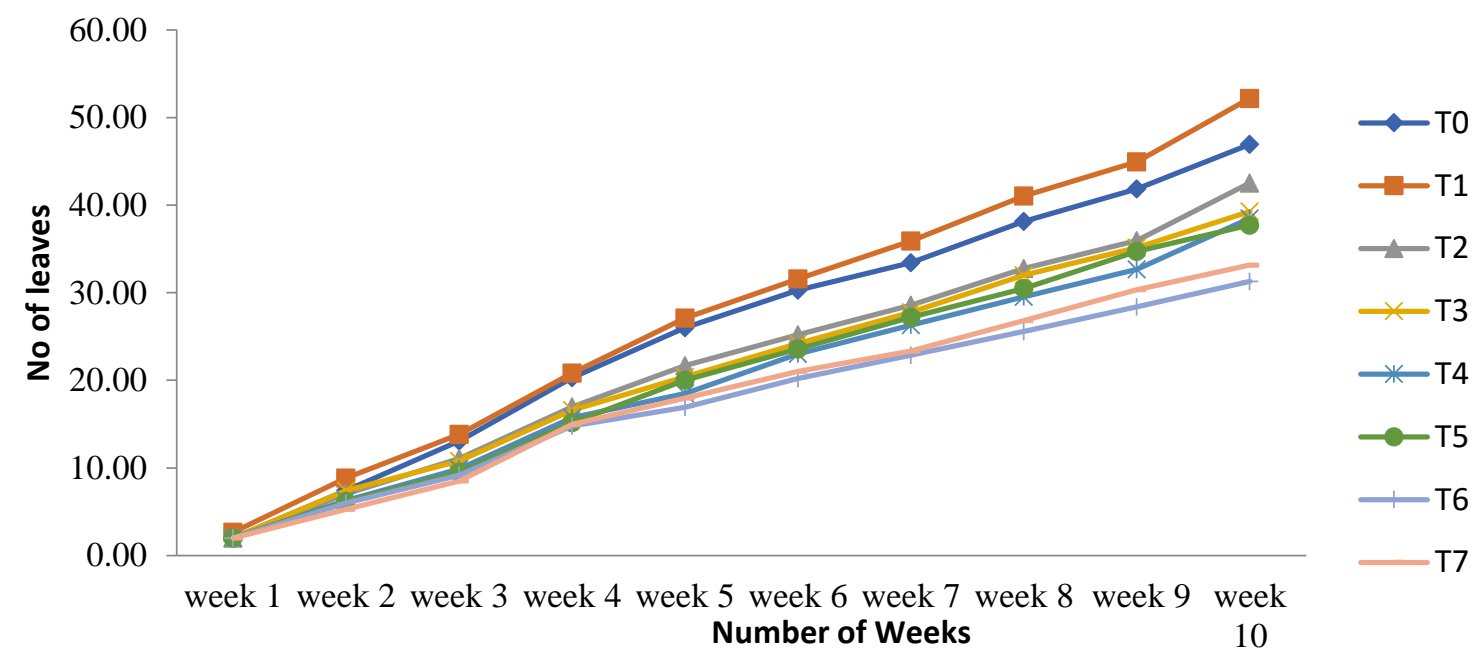

Figure 2: Number of leaves against number of weeks

\section{HEAVY METAL LOAD IN COWPEA SEED AND ROOT}

There was a significant difference $(\mathrm{P}<0.001)$ between $\mathrm{Cd}$ load both in seed and root across $\mathrm{T} 0$ and other treatment groups (Table 3). For instance, in the root, average Cd load for T0 was $0.000 \mathrm{mg} / \mathrm{kg}$; T3 was $0.0787 \mathrm{mg} / \mathrm{kg}$ while T7 was $0.2633 \mathrm{mg} / \mathrm{kg}$. Similarly, in the seed, Cd load for T0 was $0.000 \mathrm{mg} / \mathrm{kg}$, T3 was $0.0557 \mathrm{mg} / \mathrm{kg}$ and T7 was 0.1193 $\mathrm{mg} / \mathrm{kg}$. Pb was found to be absent both in seed and root across all treatment groups.

Table 3: Heavy metal load in cowpea seed and root

\begin{tabular}{|c|c|c|c|c|c|c|}
\hline Treatment & $\begin{array}{l}\text { Cadmium in } \\
\text { root }(\mathrm{mg} / \mathrm{kg})\end{array}$ & P-value & $\begin{array}{l}\text { Cadmium in seed } \\
(\mathrm{mg} / \mathrm{kg})\end{array}$ & P-value & $\begin{array}{l}\text { Lead in } \\
\text { root }(\mathrm{mg} / \mathrm{kg})\end{array}$ & $\begin{array}{l}\text { Lead in seed } \\
(\mathrm{mg} / \mathrm{kg})\end{array}$ \\
\hline T0 & $0.000 \pm 0.000$ & Ref & $0.000 \pm 0.000$ & Ref & N.d & N.d \\
\hline T1 & $0.057 \pm 0.009$ & $<0.001$ & $0.046 \pm 0.015$ & $<0.001$ & N.d & N.d \\
\hline $\mathbf{T} 2$ & $0.070 \pm 0.015$ & $<0.001$ & $0.057 \pm 0.011$ & $<0.001$ & N.d & N.d \\
\hline T3 & $0.079 \pm 0.003$ & $<0.001$ & $0.056 \pm 0.007$ & $<0.001$ & N.d & N.d \\
\hline $\mathbf{T 4}$ & $0.091 \pm 0.005$ & $<0.001$ & $0.077 \pm 0.008$ & $<0.001$ & N.d & N.d \\
\hline T5 & $0.113 \pm 0.030$ & $<0.001$ & $0.081 \pm 0.003$ & $<0.001$ & N.d & N.d \\
\hline T6 & $0.163 \pm 0.013$ & $<0.001$ & $0.102 \pm 0.014$ & $<0.001$ & N.d & N.d \\
\hline $\mathbf{T 7}$ & $0.263 \pm 0.016$ & $<0.001$ & $0.119 \pm 0.026$ & $<0.001$ & N.d & N.d \\
\hline
\end{tabular}

Values are means of 3 replicates.

N.d $=$ Not detected

\section{RELATIONSHIP BETWEEN GROWTH PARAMETERS OF COWPEA AND HEAVY METAL LOAD}

Table 4 shows a significant positive linear correlation between plant height and number of leaves $(r=0.886, P<0.001)$, $\mathrm{Cd}$ in root and $\mathrm{Cd}$ in seed $(\mathrm{r}=0.915, \mathrm{P}<0.001)$, seed weight and number of leaves $(\mathrm{r}=0.507, \mathrm{P}<0.001)$ while an inverse 
relationship was observed in $\mathrm{Cd}$ in seed and seed weight $(\mathrm{r}=-0.420, \mathrm{P}<0.001)$ and $\mathrm{Cd}$ in seed and number of leaves $(\mathrm{r}=-0.411, \mathrm{P}<0.001)$

Table 4: Relationship between growth parameters and uptake of heavy metals

\begin{tabular}{|c|c|c|c|c|c|}
\hline & Plant Height & No of leaves & $\begin{array}{c}\text { Seed } \\
\text { Weight }\end{array}$ & $\begin{array}{c}\text { Cadmium in } \\
\text { Seed }\end{array}$ & $\begin{array}{c}\text { Cadmium in } \\
\text { root }\end{array}$ \\
\hline Plant Height & 1 & & & & \\
\hline No of leaves & $0.886 * *$ & & & & \\
\hline Plant Weight & 0.102 & 1 & & & \\
\hline Seed Weight & 0.080 & $0.507 * *$ & 1 & & \\
\hline Cadmium in Seed & -0.225 & $-0.411 * *$ & $-0.420 * *$ & 1 & \\
\hline Cadmium in root & -0.116 & -0.048 & $-0.305 * *$ & $0.915 * *$ & 1 \\
\hline
\end{tabular}

\section{RELATIONSHIP BETWEEN CADMIUM IN SEED AND SEED WEIGHT}

A scatter plot of $\mathrm{Cd}$ in seed against seed weight is illustrated in figure 3 with correlation coefficient $\left(\mathrm{R}^{2}\right)$ of 0.6236 . The relationship depicts an average negative linear relationship between the concentration of $\mathrm{Cd}$ in seed and seed weight.

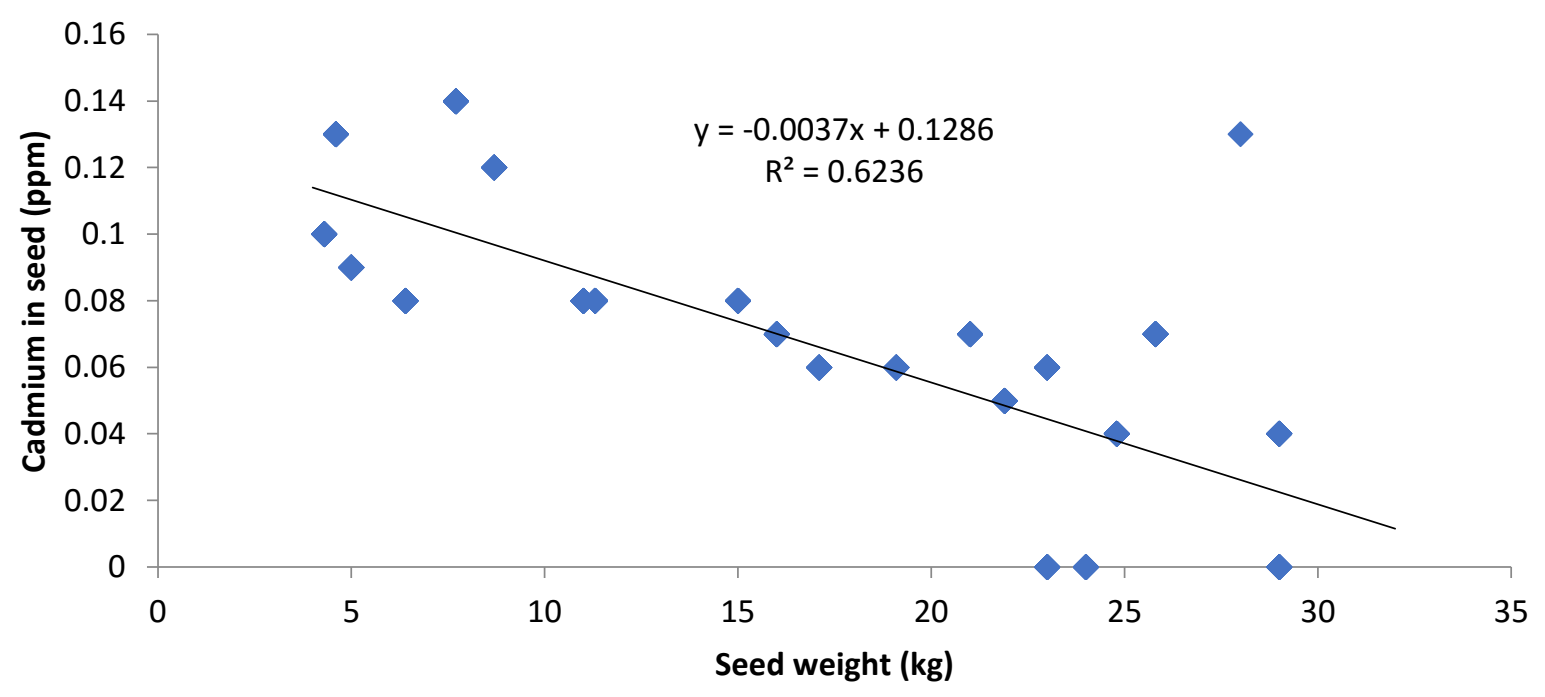

Figure 3: Relationship between $\mathrm{Cd}$ in seed and seed weight 


\section{SEED WEIGHT AND TOTAL PLANT WEIGHT}

Weights of seed and total plant across all treatment groups are presented in Figures 4 and 5. The seed weights for T3 $(16.38 \pm 6.27 \mathrm{~kg}), \mathrm{T} 5(9.66 \pm 1.76 \mathrm{~kg}), \mathrm{T} 6(5.44 \pm 1.71 \mathrm{~kg})$ and T7 $(14.21 \pm 6.74 \mathrm{~kg})$ were observed to be significantly lower compared to controls $(24.40 \pm 4.21 \mathrm{~kg}), \mathrm{p}<0.001$. Similarly, the plant weights for T3 $(136.60 \pm 66.41 \mathrm{~kg}), \mathrm{T} 5$ $(124.58 \pm 42.80 \mathrm{~kg}), \mathrm{T} 6(62.60 \pm 15.89 \mathrm{~kg})$ and T7 $(54.67 \pm 14.20 \mathrm{~kg})$ were significantly lower compared to control $(171.60 \pm 51.78 \mathrm{~kg}), \mathrm{p}<0.001$.

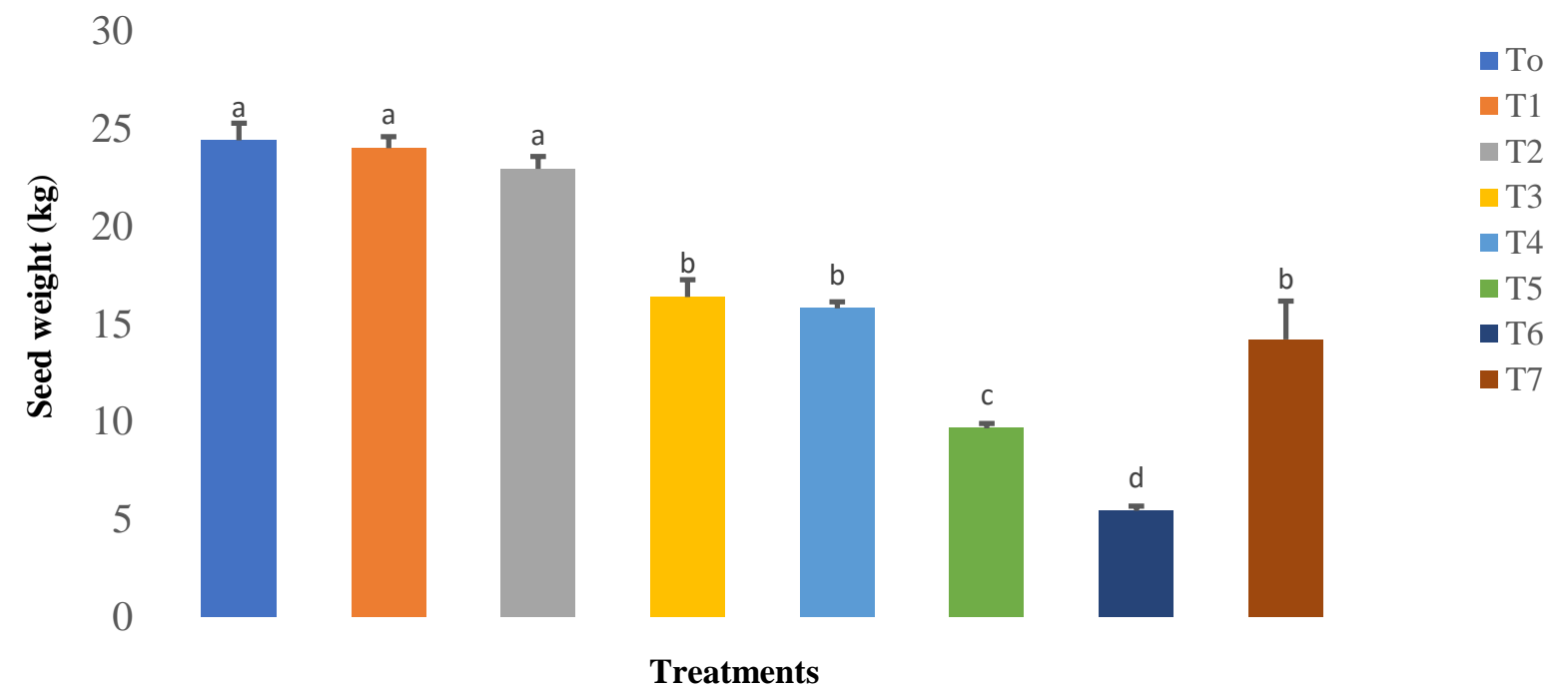

Figure 4: Seed weight across Treatment groups

*Means with the same letters are not significantly different from each other

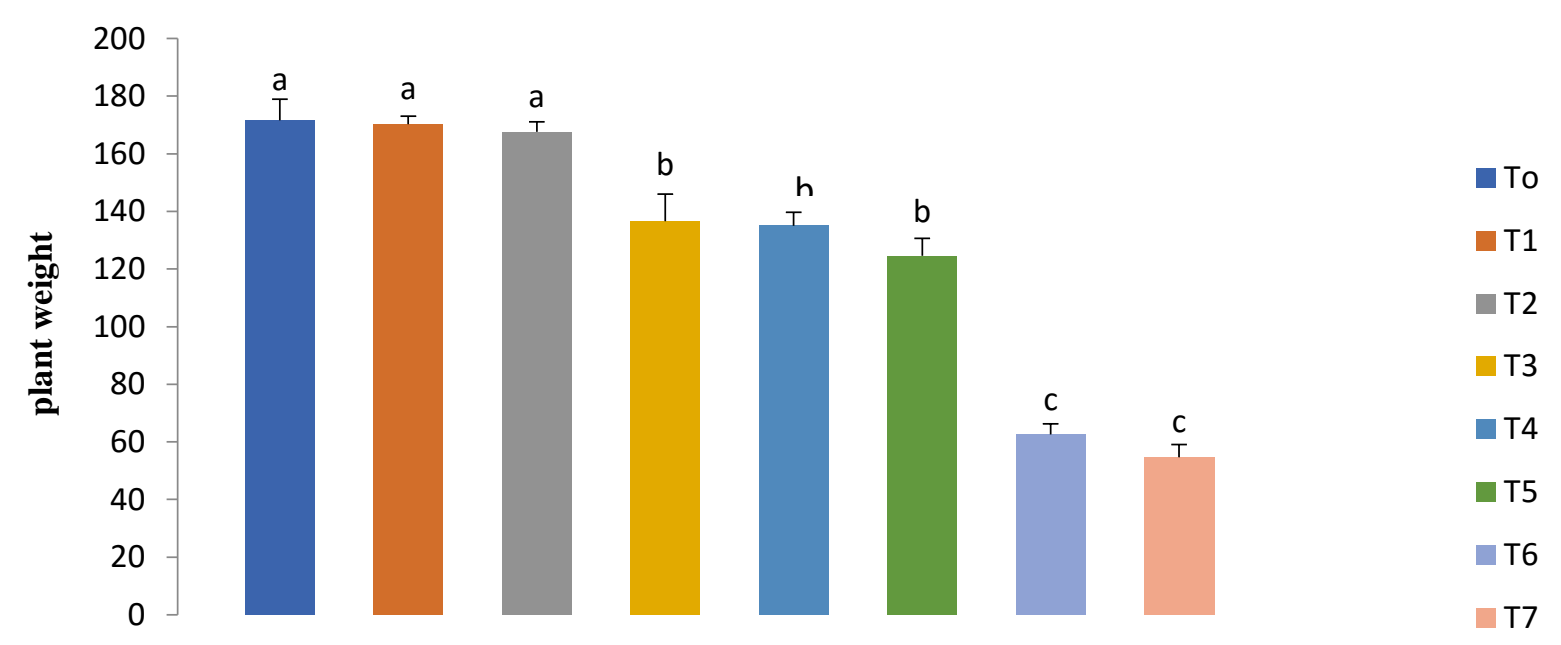

Treatment

Figure 5: Plant weight across Treatment groups

*Means with the same letters are not significantly different from each other 


\section{HEALTH RISK ASSESSMENT}

Using daily intake of cowpea as $0.1 \mathrm{~kg} /$ day, reference oral dose as $0.001 \mathrm{mg} / \mathrm{kg} / \mathrm{day}$, average body weight as $55 \mathrm{~kg}$ for various concentrations of $\mathrm{Cd}$ obtained in the study, hazard quotient increased with increasing concentrations of $\mathrm{Cd}$ albeit, they all existed far below the danger level (Table 5).

Table 5: Hazard quotient values

\begin{tabular}{ccc}
\hline Treatments & Hazard quotient & Remark \\
\hline T0 & 0.000 & \\
T1 & 0.084 & \\
T2 & 0.104 & \\
T4 & 0.102 & Hazard quotient is less than \\
T5 & 0.140 & \\
T6 & 0.147 & \\
T7 & 0.185 & \\
\hline
\end{tabular}

\section{DISCUSSION}

The absence of heavy metals from the natural soil may not be unconnected with the fact that the location where the soil samples were taken has not been involved in prior industrial or vehicular activities. However, the presence of $\mathrm{Cd}$ in the SEO may indicate the possibility of the heavy metals being picked from the circulation of oil round the engines (Whisman et al., 1974: Wang et al., 2000). This is in line with Ahamad et al. (2015) who reported presence of lead oxide, detergents and trace metals in SEO. Cheng (2003) reported that soil $\mathrm{pH}$ is the major factor affecting the mobility and bioavailability of heavy metals to plants. Thus, in the present study, soil used in the experiment presented a favourable $\mathrm{pH}$ condition for the movement of heavy metals from the soil to cowpea plant as indicated by the $\mathrm{pH}$ values of all treatments in acidic region.

A decreasing growth pattern in plant height and number of leaves from T0 to T7in this study is an indication that plant growth may be significantly impaired by SEO. In a related study, Olayinka and Arinde (2012) reported a significant reduction in plant height and number of leaves of groundnut in order of increasing SEO. Similarly, Kayode et al (2009) reported that both Zea mays and Vigna uniguiculata grew better in non-polluted soil while Vwioko and Fashem (2005) reported growth retardation in Vigna seedlings planted on SEO.

The presence of $\mathrm{Cd}$ in both seed and root of cowpea plant in this study is an indication of possible translocation of soil contaminants into various plant parts. In this study, $\mathrm{Cd}$ increased in both seed and root with increasing concentration of SEO. The inability of $\mathrm{Pb}$ to be detected in the seed and root may be due to very small quantity $(0.003 \mathrm{mg} / \mathrm{kg})$ initially present in the soil. In related studies, Adekunle et al. (2018) reported bioaccumulation of $\mathrm{Pb}$ and $\mathrm{Cd}$ in Amaranthus Cruentus L., grown on heavy metal polluted soil, while Nwite and Alu (2015) reported increased uptake of $\mathrm{Pb}$ by maize grains cultivated on SEO and Agbogidi et al. (2007) reported increasing buildup of 
heavy metals in Zea mays with increasing crude oil contamination. Mohammed and Asem (2018) also demonstrated translocation potential of heavy metals from contaminated soil to various plant areas in the order: roots > shoots > fruits which is consistent with results recorded in this present study with the order: roots > seed.

The positive correlation between plant height and number of leaves in this study shows the dependency between the two while positive correlation between $\mathrm{Cd}$ in seed and root may reflect translocation to seed based on the quantity in the root. Conversely, an inverse relationship between $\mathrm{Cd}$ in seed and seed weight may reflect the impact of heavy metal on yield. A significant difference between seed and plant weights across treatments and overall decline in seed and total plant weight recorded in this study may not be unconnected with the unfavorable conditions imposed on plant environment by the SEO. Okonokhua et al. (2007) noted a significant decrease $(\mathrm{p}<0.05)$ in grain yield planted on polluted soil in order consistent with the level of contamination. Such yield decline was also reported by Wang $e t$ al. (2002) who recorded a dry matter yield decrease to about $68 \%$.

\section{IMPLICATIONS ON HEALTH}

Ingestion of heavy metals through consumption of contaminated crops may constitute health risk to consumers of such crops particularly if accumulated to elevated concentration (Gupta and Gupta, 1998). According to Food and Agriculture Organization (2017), the maximum intake limits of 0.3 and $0.2 \mathrm{mg} / \mathrm{kg}$ for $\mathrm{Pb}$ and $\mathrm{Cd}$ were recommended in green leafy vegetables by Committee of food additives and contaminants. The concentrations of cadmium recorded in the seeds of cowpea used in this study were below the limit set by the committee. Similarly, hazard quotients obtained across all treatments were less than $\mathbf{1}$ thus, adverse effects are unlikely via ingestion of cowpea used in this study. However, planting on heavily polluted soil may pose serious danger of higher accumulation as exemplified in the increasing hazard quotient with increasing concentration of SEO. Continuous intake of crops grown on polluted soils even with low metal concentrations may biomagnify in human systems (Pinto et al., 2003: Patra et al., 2011; Carneiro et al., 2018) and this may cause serious health problems.

\section{CONCLUSION}

SEO affected the growth of cowpea cultivated on contaminated soil by causing a significant reduction in plant growth and yield as well as contaminating the plants with heavy metals. Hazard quotient increased with increased contamination hence, the need for integrated health risk assessment for inhabitants of areas polluted with such contaminants. 


\section{REFERENCES}

Adekunle, S.T, Oloruntoba, E.O., Fayinminnu, O.O. and Fakunle, A.G. (2018). Cadmium Bioaccumulation in Amaranthus cruentus L. and its Health Implication. Journal of Environmental Science, Toxicology and Food Technology 12(6) 39-49. DOI: 10.9790/2402-1206023949

Adedokun, O.M. and Ataga, A.E. (2007). Effect of Amendment and Bioaugmentation of soil polluted with crude oil Automotive Gasoline and Spent Engine oil on the growth of cowpea (Vigna unguiculata L. walp). Scientific Research and Essay 2(5): 147-149. http://www.academicjournals.org/SRE

Agbogidi, O.M., Eruotor, P.G. and Akparobi, S.O. (2007). Effects of Crude Oil Levels on the Growth of Maize (Zea mays L.). American Journal of Food Technology 2(6): 529-535. DOI: 10.3923/ajft.2007.529.535

Ahamad, Md, T., Chadraasekhar, B.P., Mohan, P.N., Joshi, K.S. and Sree, T.D.R. (2015). Recycling and Analysis of Spent Engine Oil. International Journal of Scientific and Engineering Research 6 (11):711-717.

Akinola, O., Udo, A.S. and Okwok, N. (2004). Effect of crude oil (Bonny Light) on germination, early seedling growth and pigment content in maize (Zea mays L.) Journal of Science, Technology and Environment $\mathbf{4}(1$ and 2): 6-9.

Anderson, J. W. and Major, A. W. (2002). Pulses and lipemia, short- and long-term effect: potential in the prevention of cardiovascular disease. British Journal of Nutrition 88: Suppl. 3; 263. DOI: 10.1079/BJN2002716.

Anoliefo, G, O. and Vwioko, D.E (2001). Tolerance of Chromolaena odorata $(L) K$. and R. grown in soil contamination with spent lubrication oil. Journal of Tropical Biosciences 1:20-24.

Baker, A.J.M., McGrath, S.P., Reeves, R.D. and Smith, J.A.C. (2000). Metal hyperaccumulator plants: a review of the ecology and physiology of a biological resource for phytoremediation of metal polluted soils. In: Terry N., Bañuelos G. (eds.): Phytoremediation of Contaminated Soil and Water. Boca Raton, CRC Press, pp 85107. ISBN 9780367399436

Bouchenak, M. and Lamri-Senhadji, M. (2013) Nutritional quality of legumes and their role in cardiometabolic risk prevention: a review. Journal of Medicinal Food 16 (3): 185-98. DOI: 10.1089/jmf.2011.0238

Carneiro, M.F.H., Barcelos, G.R.M., Barbosa, F., Adeyemi, J. and Gobe, G. (2018). Metal and metalloidinduced oxidative damage: biological importance of potential antioxidants. Oxidative Medicine and Cellular Longevity 1-2. pmid:30147832

Cheng, S. (2003): Effect of heavy metals on plants and resistance mechanisms. Environmental Science and Pollution Research 10(4):256-264. doi: 10.1065/espr2002.11.141.2

Cho-Ruk, K., Kurukote, J., Supprung, P., and Vetayasuporn, S. (2006). Perennial plants in the phytoremediation of lead-contaminated soils. Biotechnology 5(1): 1-4.

FAO (2017). FAOSTAT Online Statistical Services: Crop production data. Food and Agriculture Organization of the United Nation (FAO), Rome. Available at: http://www.fao.org/faostat/en/\#data/QC (accessed on: 24 Au-gust 2017)

Gupta, U.C. and Gupta, S.C. (1998). Trace element toxicity relationships to crop production and livestock and human health: implications for management. Journal of Communications in Soil Science and Plant Analysis 29 (11-14):1491-1522.https://doi.org/10.1080/00103629809370045 
Indian Council of Medical Research (ICMR) (2010). Nutrient Requirements and Recommended Dietary

Allowance for Indians. A Report of the Expert Group of the Indian Council of Medical Research, New Delhi.

Kayode J., Olowoyo, O. and Oyedeji, A. (2009). The Effects of Used Engine Oil Pollution on the Growth and Early Seedling Performance of Vigna uniguiculata and Zea mays. Research Journal of Soil Biology 1: 1519.DOI: $10.3923 /$ rjsb.2009.15.19

Langyintuo, A. S., Lowenberg-DeBoer, J., Faye, M., Lambert, D., Ibro, G., Moussa, B., Kergna, A., Kushwaha, S., Musa, S. and Ntoukam, G. (2003). Cowpea supply and demand in West and Central Africa. Field Crops Research. 82(2-3): 215-231.https://doi.org/10.1016/S0378-4290(03)00039-X

Marinangeli, C.P.F., Curran, J., Barr, S.I., Slavin, J., Puri, S., Swaminathan, S., Tapsell, L. and Patterson, C.A. (2017). Enhancing nutrition with pulses: defining a recommended serving size for adults Nutrition Reviews 75(12): 990-1006. doi: 10.1093/nutrit/nux058

Meagher, R.B. (2000). Phytoremediation of toxic elemental and organic pollutants. Current Opinion in Plant Biology 3(2): 153-162.DOI: 10.1016/s1369-5266(99)00054-0

Youssef, M.A., Abd El-Gawad, A.M. (2018). Accumulation and Translocation of Heavy Metals in Eggplant (Solanum melongena L.) Grown in a Contaminated Soil. Journal of Energy, Environmental and Chemical Engineering. 3: (1):9-18. doi: 10.11648/j.jeece.20180301.12

Nwite, J. N. and Alu, M. O. (2015). Effect of different levels of spent engine oil on soil properties, grain yield of maize and its heavy metal uptake in Abakaliki, South eastern Nigeria. Journal of Soil Science and Environmental Management. 5(4): 44-51.DOI 10.5897/JSSEM12.070

Odjegba, V.J. and Sadiq, A.O. (2002). Effects of spent engine oil on the growth parameters, chlorophyll and protein levels of Amaranthus hybridus $L$ The Environmentalist 22:23-28 https://doi.org/10.1023/A:1014515924037

Okonokhua, B O., Ikhajiagbe, B., Anoliefo, G O. and Emede, T O. (2007). The Effects of Spent Engine Oil on Soil Properties and Growth of Maize (Zea mays L.). Journal of Applied Science, Environmental Management. 11 (3) 147 - 152. www.bioline.org.br/ja.

Olayinka, B.U. and Ayinde, O.O. (2012). Effect of spent engine oil on germination and seedling growth of groundnut (Arachis hypogaea L.). Insight Ethnopharmacology 2 (1): 5-9. Doi:10.5567/ETHNOPHARMAIK2012.5.9

Patra, R.C., Rautray, A.K. and Swarup, D. (2011) Oxidative stress in lead and cadmium toxicity and its amelioration. Veterinary Medicine International. 2011:457327 doi: 10.4061/2011/457327.

Pinto, E., Sigaud-kutner, T.C.S., Leitao, M.A.S., Okamoto, O.K., Morse, D. and Colepicolo, P. (2003). Heavy Metal-Induced Oxidative Stress in Algae. Journal of Phycology 3:1008-1018.

Raskin, I. and Ensley, B.D. (2000) Phytoremediation of Toxic Metals: Using Plants to Clean up the Environment. $\left(1^{\text {st }}\right.$ edition pp 53-70). John Wiley \& Sons, Inc., New York.

Saka, O.J., Adeola, A., Ayoola, O.T., Lawal, O.A., Adedayo. J.A. and Oloyede-Kamiyo, Q.O. (2018). Assessment of varietal diversity and production systems of cowpea (Vigna unguiculata (L.) Walp.) in Southwest Nigeria. Journal of Agriculture and Rural Development in the Tropics and Subtropics 119(2): 4352 DOI:10.17170/kobra-2018121864

Tharanathan, R. N. and Mahadevamma, S. (2003). Grain legumes - a boon to human nutrition. Trends in Food Science and Technology 14(12):507-518 https://doi.org/10.1016/j.tifs.2003.07.002

US Environmental Protection Agency (US EPA) (1989). Risk assessment guidance for superfund: Human Health 
Evaluation Manual [part A]: Interim final. U.S. Environmental Protection agency, Washington, DC, USA [EPA/540/1-89/002]

United States Environmental Protection Agency (US EPA) (2000). Risk-Based Concentration Table. Washington Agency, United States Environmental Protection Agency; Washington, DC, USA.

Vwioko, D.E. and Fashemi, D.S. (2005). Growth response of Ricinus communis L. in spent lubricating oil polluted soil. Journal of Applied Science and Environmental Management 9 (2): 73-79.DOI: 10.4314/jasem. v9i2.17294

Wang, J., Jiq, C R., Wong, C K. and Wong, P K. (2000). Characterisation of polycyclic aromatic hydrocarbons created in lubricating oils. Water, Air and Soil Pollution 120: 381-396. https://doi.org/10.1023/A:1005251618062

Wang, Q.R., Liu, X.M., Cui, Y.S., Dong, Y.T. and Christie, P. (2002). Responses of legume and non-legume crop species to heavy metals in soils with multiple metal contamination. Journal of Environmental Science and Health. Part A, Toxic/Hazardous Substances and Environmental Engineering 37:(4):611-621. DOI: $10.1081 /$ ese-120003241

Whisman, M.L., Goetzinger, J.W. and Cotton, F.O. (1974). Waste lubricating oil research. In: An Investigation of Several Re-fining Methods. Bureau of mines, Bartlesville, Energy Research Center, Okla (USA) 